\title{
EFEKTIVITAS LEMBAR KERJA SISWA DENGAN MODEL PROBLEM BASED LEARNING PADA MATERI BANGUN RUANG SISI DATAR KELAS VIII SMP
}

\author{
Windrianto $^{1}$, Rusdi ${ }^{2}$, Syafdi Maizora ${ }^{3}$ \\ 1,2,3 Program Studi Pendidikan Matematika JPMIPA FKIP Universitas Bengkulu \\ email : ${ }^{1}$ windri.anto95@gmail.com, ${ }^{2}$ rusdipendmat12@gmail.com, ${ }^{3}$ syafdiichiemaizora@unib.ac.id
}

\begin{abstract}
Abstrak
Penelitian ini bertujuan untuk menghasilkan LKS matematika model problem based learning pada materi bangun ruang sisi datar kelas VIII di SMP Negeri 2 Kota Bengkulu yang memiliki validitas, kepraktisan, dan efektifitas yang baik. Penelitian ini adalah penelitian pengembangan dengan mengadopsi prosedur 4-D yaitu tahap pendifinisian, tahap perancangan, dan tahap pengembangan yang terdiri dari uji validitas, uji kepraktisan, dan efektifitas.Instrument penelitian ini adalah lembar validasi LKS, lembar kepraktisan LKS, dan lembar keefektifan yang terdiri dari: lembar aktivitas siswa, lembar respon siswa, dan lembar tes hasil belajar siswa. Semua data yang dikumpulkan dianalisis kevalidan, kepraktisan dan keefektifannya. Hasil penelitian menunjukan bahwa : (a) LKS Matematika Model Problem Based Learning di SMP Negeri 2 Kota Bengkulu termasuk dalam kategori sangat valid dari aspek materi dan kontruksi dengan skor rata-rata $=4,47$, (b) LKS Matematika Model Problem Based Learning di SMP Negeri 2 Kota Bengkulu termasuk dalam kategori sangat praktis dengan skor rata-rata $=4,59$, (c) LKS Matematika Model Problem Based Learning di SMP Negeri 2 Kota Bengkulu termasuk dalam kategori sangat efektif dengan skor ratarata $=4,31$ dan pencapaian efektifitas: (1) penilaian aktivitas siswa sangat efektif dengan skor rata-rata sebesar $=4,47$; (2) penilaian respon siswa sangat efektif dengan skor rata-rata $=4,33$; (3) penilaian tes hasil belajar siswa efektif dengan skor rata-rata $=4,18$.
\end{abstract}

Kata kunci : lembar kerja siswa, problem based learning, bangun ruang sisi datar.

\begin{abstract}
The purpose of this research was to produce Students' Worksheet of Problem Based Learning for Geometry Solids lesson at grade VIII SMPN 2 Bengkulu City with criteria validity, practicality and effectiveness. The type of this research was a research and development by adopting procedure of 4-D: define, design, and develop that consists of validity, practicality, and effectiveness. The instruments of this study were validation sheets, construct practicality sheets, and effectiveness sheets which consist of activity sheets, respons sheets, and test. The result of the reaserch showed that: a) Students' Wokrheet of mathematics of Problem Based Learning was valid from the aspect materials and construct with the average score 4,47, b) Students' Wokrheet of mathematics of Problem Based Learning was very practis with the average score 4,59, c) Students' Wokrheet of mathematics of Problem Based Learning was very effective with the average score 4,31. Besides that, the effectiveness achievement were: 1) scoring the studens effective work with the average score 4,47, 2) scoring the studens respons with the average score 4,33, 3) scoring the studens test with theaverage score 4,18.

Keywords : students' worksheet, problem based learning, geometry solids.
\end{abstract}

\section{PENDAHULUAN}

Mengingat pentingnya matematika, maka banyak upaya yang dilakukan guru untuk memotivasi dan menumbuhkan minat belajar siswa serta meningkatkan hasil belajar siswa. Upaya pendekatan metode serta model pembelajaran telah dilakukan untuk memahami matematika dengan mudah. Pendekatan metode dan model tersebut bertujuan untuk mengoptimalkan proses pembelajaran.

Kehadiran bahan ajar di dalam dunia pendidikan mempunyai arti penting dalam proses pembelajaran, karena dengan adanya bahan ajar memungkinkan siswa dapat mempelajari suatu kompetensi secara runtut 
dan sistematis sehingga secara akumulatif mampu menguasai semua kompetensi secara utuh dan terpadu. Salah satu bahan ajar yang dapat digunakan adalah Lembar Kerja Siswa (LKS). LKS merupakan suatu bahan ajar cetak berupa lembar-lembar kertas yang bersisi materi, ringkasan, dan petunjuk-petunjuk pelaksanaan tugas-tugas pembelajaran yang harus dikerjakaan oleh peserta didik, yang mengacu pada kompetensi dasar yang harus di capai (Prastowo, 2013:204). Salah satu kelebihan dari LKS adalah materi yang disampaikan secara ringkas dan jelas sehingga tidak membingungkan siswa dan LKS dilengkapi dengan soal-soal yang beragam. Tentunya LKS tidak hanya berupa ringkasan materi dan soal, tetapi juga memberikan kesempatan pada siswa untuk terlibat secara aktif dalam proses pembelajaran untuk menemukan dan memahami konsep-konsep matematika yang dipelajari dengan melibatkan guru pembimbing. Guru pembimbing adalah seseorang yang memahami proses pembelajaran yang berlangsung. Guru pembimbing bertugas untuk membimbing atau mengarahkan siswa dalam proses pembelajaran untuk mencapai tujuan pembelajaran.

Pada saat ini, LKS yang digunakan di sekolah-sekolah berupa LKS yang dibeli dari berbagai penerbit. LKS tersebut hanya menekankan rumus tanpa menjelaskan proses diperolehnya rumus tersebut. Pembelajaran yang menggunakan LKS seperti ini memiliki keterbatasan dalam meningkatakan kompetensi siswa.Namun pada umumnya LKS tersebut kebanyakan hanya memuat soal-soal. Jarang sekali ada LKS yang diawali dengan memberikan masalah nyata, kemudian siswa diminta untuk menyelesaikannya dengan diberikan langkah-langkah yang menuntun siswa. Oleh karena itu, perlu dikembangkan suatu LKS berbasis masalah yang diharapkan dapat meningkatkan kemampuan atau hasil belajar siswa. LKS berbasis masalah sebagaimana dimaksud sebelumnya adalah LKS dengan model Problem Based Learning (PBL).

Problem Based Learning (PBL) merupakan proses pembelajaran yang titik awal pembelajarannya berdasarkan masalah dan dari masalah ini dirangsang untuk mempelajari objek berdasarkan pengetahuan dan pengalaman yang telah mereka punyai sebelumnya sehingga akan terbentuk pengalaman dan pengetahuan yang baru. Menurut Tan (Rusman, 2013:229) pembelajaran berbasis masalah merupakan inovasi dalam pembelajaran karena dalam pembelajaran berbasis masalah kemampuan berpikir siswa betul-betul dioptimalisasikan melalui proses kerja kelompok atau tim yang sistematis, sehingga siswa dapat memberdayakan, mengasah, menguji, dan mengembangkan kemampuan berpikirnya secara berkesinambungan.

\section{METODE}

Jenis penelitian yang digunakan adalah penelitian dan pengembangan (Research and Development).Metode penelitian dan pengembangan adalah "metode penelitian yang digunakan untuk menghasilkan produk tertentu, dan menguji keefektifan produk tersebut" (Sugiyono, 2011:297).

Sasaran dalam penelitian ini adalah 6 siswa kelas VIII I uji kepraktisan dan 34 siswa VIII $\mathrm{H}$ uji keefektifan. Prosedur penelitian pengembangan ini dimodifikasi dari model pengembangan perangkat pembelajaran 4D.Model pengembangan perangkat pembelajaran 4D dikembangkan oleh Thiagarajan, Dorothy Semmel, dan Melvyn Semmel yang terdiri dari 4 tahap yaitu define, design, develop, dan disseminate (Trianto,2011:190).

Instrumen Penelitianyang digunakan dalam penelitian ini yaitu : (1) Lembar Validasi LKS, (2) Lembar kepraktisan LKS; (3) Lembar keefektifan LKS yang terdiri dari lembar aktivitas siwa, lembar respon siswa, dan lembar tes hasil belajar siswa.

Teknik analisis data:

1. Analisis validitas

$\bar{V}=\frac{\sum_{1}^{n} R A_{i}}{n}$ (Sudjana, 1995:67)

Keterangan :

$\bar{V}=$ Skor rata-rata validitas

$R A_{i}=$ Skor rata-rata validasi aspek ke- $i$

$\mathrm{n} \quad=$ Banyaknya aspek 
Skor rata-rata validitas yang diperoleh dibandingkan dengan kriteria:

Tabel 1. Kriteria Skor Kevalidan dan Kepraktisan

\begin{tabular}{|c|c|}
\hline Rentang Kevalidan & Kriteria \\
\hline $1 \leq \bar{V}<1,8$ & Tidak Valid \\
\hline $1,8 \leq \bar{V}<2,6$ & Kurang Valid \\
\hline $2,6 \leq \bar{V}<3,4$ & Cukup Valid \\
\hline $3,4 \leq \bar{V}<4,2$ & Valid \\
\hline $4,2 \leq \bar{V}<5$ & Sangat Valid \\
\hline & Sumber: Maizora (2011)
\end{tabular}

2. Analisis Efektivitas nilai rata-rata keefektifan digunakan rumus: $\bar{E}=\frac{(\overline{A S} X 30 \%)+(\bar{R} X 30 \%)+(\overline{H B} \times 40 \%)}{100 \%}$

Keterangan:

$\bar{E}=$ Nilai rata-rata keefektifan

$\bar{A}=$ Nilai rata-rata aktifitas siswa

$\bar{R}=$ Nilai rata-rata respon siswa

$\bar{H}=$ Nilai rata-rata tes hasil belajar siswa

Skor rata-rata keefektifan yang diperoleh dibandingkan dengan kriteria:

Tabel 2. Kriteria Skor Keefektifan

\begin{tabular}{|c|c|}
\hline $\begin{array}{c}\text { Rentang } \\
\text { Efektifitas }\end{array}$ & Kriteria \\
\hline $1 \leq \bar{E}<1,8$ & Tidak Efektif \\
\hline $1,8 \leq \bar{E}<2,6$ & Kurang Efektif \\
\hline $2,6 \leq \bar{E}<3,4$ & Cukup Efektif \\
\hline $3,4 \leq \bar{E}<4,2$ & Efektif \\
\hline $4,2 \leq \bar{E}<5$ & Sangat Efektif \\
\hline
\end{tabular}

Sumber: Maizora (2011)

\section{HASIL DAN PEMBAHASAN}

\section{A. Hasil Penelitian}

\section{A.1 Hasil Uji Validitas}

a. Validitas Materi

Hasil validasi materi keempat LKS oleh kedua validator dapat dilihat pada tabel 3 .

Tabel 3. Rata-Rata Skor Validasi Materi

\begin{tabular}{|r|c|c|}
\hline \multicolumn{1}{l|}{ No } & Rata-Rata & Skor Rata-Rata \\
\hline 1 & LKS 1 & 4,56 \\
\hline 2 & LKS 2 & 4,45 \\
\hline 3 & LKS 3 & 4,44 \\
\hline 4 & LKS 4 & 4,44 \\
\hline \multicolumn{2}{|c|}{ Rata-rata Skor } \\
kedua validator
\end{tabular}

Dari rata-rata skor validasi materi keempat LKS dengan kriteria sangat valid.

b. Validitas Konstruksi

LKS termasuk dalam kriteria sangat valid dengan skor rata-rata 4,46 dengan kriteria sangat valid. Hal ini menunjukan bahwa konstruksi pada LKS telah sesuai.Validasi kontruksi dilakukan sebanyak 2 kali, pada tahap pertama validator memberikan revisi, setelah direvisi dan divalidasi kembali validator menyetujui untuk diujikan ke kelompok kecil.

Hasil validasi dari kedua bagian yaitu materi dan konstruksi secara umum diperoleh skor rata-rata 4,47. Skor tersebut termasuk dalam kategori "Sangat Valid".Hal ini berarti LKS sangat layak digunakan baik dari segi materi dan konstruksi.

\section{A.2 Hasil Uji Kepraktisan}

Uji praktikalitas dilakukan setelah proses validasi selesai dan digunakan untuk mendapatkan LKS yang praktis bagi siswa. Hasil uji kepraktisan dari lembar kepraktisan siswa mendapatkan rata-rata skor 4,59 dengan kriteria "Sangat Praktis". Maka untuk skor ratarata sudah memenuhi kategori praktis. Dengan demikian, LKS ini dapat digunakan untuk proses belajar mengajar materi bangun ruang sisi datar di kelas VIII I.

\section{A.3 Hasil Uji Keefektifan}

Uji efektivitas diujicobakan pada 34 siswa kelas VIII H SMP Negeri 2 Kota Bengkulu yang sedang mendapatkan pembelajaran bangun ruang sisi datar.

Berdasarkan perhitungan nilai efektivitas diperoleh nilai uji efektivitas sebesar 4,31. Dari data yang diperoleh terlihat bahwa LKS yang telah dikembangkan dikategori sangat efektif. Hal ini menunjukkan bahwa LKS yang dikembangkan sangat layak digunakan dalam proses pembelajaran yakni mengefektifkan aktivitas dalam kegiatan belajar, respon dan hasil belajar siswa. 


\section{B. Pembahasan}

\section{B.1 Validitas}

a. Validitas Materi

Validasi materi terdiri dari dua validator.Validator pertama mevalidasi LKS sebanyak tiga kali validasi. Pada validasi pertama menghasilkan LKS yang belum valid sehingga dilakukan revisi, adapun revisi pada validasi pertama sebagai berikut :

1) Sintaks PBL masih kurang tahap "memeriksa hasil"

2) LKS masih seperti discovery learning, siswa terlalu dibimbing dengan gambar dan tabel.

Sedangkan validator kedua memvalidasi sebanyak satu kali validasi.Validator kedua memvalidasi setelah validator pertama menyatakan LKS telah valid.

b. Validitas Konstruksi

Berdasarkan hasil uji validasi konstruksi LKS yang dinilai oleh validator terdapat dua kali revisi dan saran-saran untuk perbaikan.Pada validasi pertama validator hanya memberikan revisi untuk perbaikan pada LKS.

Setelah revisi pada validasi pertama diperbaiki LKS yang dikembangkan kembali divalidasi oleh validator.Pada validasi kedua LKS yang dikembangkan validator menyatakan bahwa LKS yang telah direvisi dinyatakan valid.Kriteria tersebut didapatkan dari hasil penilaiaan validator pada lembar validasi konstruksi.

Dari hasil validasi materi dan validasi konstruksi setelah LKS yang dikembangkan telah valid oleh validator maka LKS yang dikembangkan boleh diujikan pada tahap kepraktisan.

\section{B.2 Kepraktisan}

Uji kepraktisan dilaksanakan pada siswa kelas VIII I. Proses pelaksanaan uji kepraktisan dilakukan pada waktu jam pelajaran matematika. Pada saat pengerjaan LKS seluruh siswa kelas VIII I mengerjakan LKS secara berkelompok. Dari hasil LKS yang dikerjakan siswa pada tahap kepraktisan terlihat siswa dapat mengusai materi, hanya saja di awal masuk atau pada saat mengerjakan LKS 1 ada beberapa siswa meminta penjelasan di tahap penyelidikan, tahap penyajian, dan tahap memeriksa. Disini guru sebagai pembimbing siswa dalam menyelesaikan LKS maka guru menjelaskan apa yang telah ditanya oleh siswa. Pada tahap penyelidikan siswa meminta gambaran penyelesaian dengan cara berbedabeda. Guru mengarahkan siswa agar menyelesaikan dari cara yang lebih dasar dengan menghitung banyak kubus secara keseluruhan, kemudian dengan mengalikan luas salah satu sisinya terhadap sisi yang lain, dan sampai pada tahap yang berikutnya mengarahkan siswa untuk mencoba dengan mengalikan bagian dari sisi-sisinya. Dari beberapa cara yang dikerjakan, siswa diminta untuk melihat jawabannya apakah sama.

Berdasarkan uji kepraktisan yang telah dilakukan, LKS dinyatakan sangat praktis dengan nilai 4,59. Oleh karena itu, LKS dapat digunakan dalam proses pembelajaran bangun ruang sisi datar.

\section{B.3 Keefektifan}

Dalam penelitian ini uji efektifitas dilakukan terhadap 34 siswa kelas VIII H SMP Negeri 2 Kota Bengkulu. Uji efektifitas dilakukan sebanyak lima kali pertemuan yang terdiri dari empat pertemuan pembelajaran menggunkan LKS dan satu pertemuan untuk tes hasil belajar.

Pada uji efektifitas digunakan lembar pengamat aktivitas siswa yang diisi oleh pengamat dalam hal ini pengamat adalah guru yang bertanggung jawab dalam mengajar matematika di kelas tersebut, kemudian lembar angket respon siswa, dan tes hasil belajar siswa. Tujuan efektifitas yang diukur adalah untuk mengefektifkan aktivitas dalam kegiatan belajar yang terdiri dari aktivitas siswa, respon siswa terhadap LKS, dan tes hasil belajar siswa setelah proses pembelajaran.

Aktivitas siswa dalam proses pembelajaran dianalisis melalui hasil penilaian lembar aktivitas siswa dan pengamatan langsung oleh pengamat dan peneliti. Skor aktivitas siswa dari pengamat akan menunjukan tingkat aktivitas siswa selama pembelajaran. Aktivitas siswa dinilai setiap kali pertemuan dan selama proses pembelajaran berlangsung. 
Respon siswa dalam proses pembelajaran dianalisis melalui hasil penilaian lembar respon siswa yang diisi oleh setiap siswa yang mengikuti pelajaran dalam menyelesaikan LKS. Lembar respon yang diisi oleh siswa berupa tanggapan siswa terhadap penyelsaian LKS yang diberikan, apakah LKS yang diberikan memudahkan siswa dalam memahami materi bangun ruang sisi datar, hal ini dilihat dari skor rata-rata respon dari siswa. Jika skor respon yang diberikan siswa semakin besar, maka tanggapan siswa semakin baik terhadap LKS dengan model Problem Based Learning yang diberikan.Dalam hal ini siswa memberikan respon yang sangat baik terhadap LKS yang diberikan. Artinya siswa sangat tertarik dalam menyelsaikan LKS bangun ruang sisi datar dengan model Problem Based Learning yang diberikan.

Tes hasil belajar siswa dianalisis melalui hasil belajar siswa setelah proses pembelajaran menggunakan LKS. Tes hasil belajar siswa diperoleh dari lembar soal yang diberikan dan dijawab oleh siswa.Lembar soal tersebut sebelum diberikan kepada siswa divalidasi oleh validator terlebih dahulu, kemudian setelah soal tersebut direvisi, diperbaiki, dan dinyatakan valid oleh validator berarti tes hasil belajar yang dibuat dapat digunakan untuk menilai kemapuan siswa.Soal tes hasil belajar siswa sebanyak 4 buah soal yang telah mencangkup seluruh materi yang telah diajarkan dengan menggunakan LKS. Tes hasil belajr siswa diikuti oleh 34 siswa. Dari perhitungan tes hasil belajar siswa mendapatkan skor rata-rata 4,18 dengan kategori efektif. Hal ini menunjukan bahwa siswa telah mampu mencapai kompetensi dan indikator pencapaian pembelajaran.

Hasil dari aktivitas siswa, respon, dan tes hasil belajar siswa merupakan hasil yang diberikan pada uji efektifitas LKS yang dikembangkan.LKS yang telah dikembangkan telah dikatakan efektif dalam pembelajaran bangun ruang sisi datar berdasarkan uji efektifitas yang telah dilakukan. Hasil penelitian berupa produk final dari LKS yang dikembangkan dengan model Problem Based Learning pada materi bangun ruang sisi datar yang valid, praktis dan efektif.

\section{PENUTUP \\ Simpulan}

Berdasarkan hasil penelitian Pengembangan Lembar Kerja Siswa (LKS) dengan Model Problem Based Learning Pada Materi Bangun Ruang Sisi Datardi Kelas VIII SMPNegeri 2 Kota Bengkulu diperoleh kesimpulan sebagai berikut :

1. Hasil analisis validitas Lembar Kerja Siswa (LKS) termasuk dalam kategori "sangat valid" dengan skor rata-rata 4,47 berdasarkan aspek materi pada LKS telah memenuhi kompetensi inti dan kompetensi dasar, aspek materi pada LKS telah memenuhi pembelajaran dengan model Problem Based Learningyang efektif yang dapat menuntun siswa menemukan konsep, ketepatan bahasa yang mudah dipahami siswa, dan aspek konstruksi telah memenuhi format dan bagian-bagian yang telah ditetapkan pada LKS.

2. Hasil analisis kepraktisan LKS termasuk dalam kategori "sangat praktis" dengan skor rata-rata kepraktisan 4,59 berdasarkan petunjuk pengguanaan LKS membantu dalam menggunakan LKS, LKS memiliki tulisan yang mudah dibaca, LKS memiliki warna yang cocok untuk dilihat, kalimat dalam LKS mudah dimengerti, isi LKS membantu memahami materi pelajaran, LKS mudah digunakan, tampilan LKS menarik, dan masalah yang disajikan sesuai dengan materi.

3. Hasil analisis efektivitas LKS termasuk dalam kategori efektif dengan skor ratarata efektivitas 4,31 berdasarkan aktivitas siswa aktif dalam pembelajaran, LKS mampu mengeksplorasikan pengetahuan siswa, LKS memberikan respon positif dari siswa, dan LKS mampu menghasilkan hasil belajar yang baik. 


\section{Saran}

Berdasarkan penelitian yang telah dilakukan, peneliti menyarankan beberapa hal berikut :

1. Pada pengembangan lembar kerja siswa (LKS) dengan model Problem Based Learning (PBL) selanjutnya menambahkan validasi bahasa agar LKS yang dikembangkan sesuai dengan EYD.

2. Pada penelitian pengembangan LKS dengan model PBL bagusnya menampilkan gambar pada masalah sehingga tidak banyak memakan waktu dalam penyelesaian LKS sehingga pembelajaran bisa semakin efektif.

3. Pada uji kepraktisan Pengembang (LKS) dengan model Problem Based Learning(PBL) hendaknya kelompok yang dibentuk minimal 5 kelompok.

4. Berdasarkan uji efektifitas pada pengembangan LKS dengan model PBL waktu yang diberikan sesuaikan dengan runtunan pengerjaan masalah yang disajikan.

\section{DAFTAR PUSTAKA}

Maizora, S. 2011. Pengembangan Web Pembelajaran Kalkulus Diferensial Pada Program Studi Pendidikan Matematika FKIP Universitas Bengkulu. Tesis Konsentrasi Pendidikan Matematika Program Pascasarjana UNP (Tidak Diterbitkan).

Prastowo, Andi. 2013. Panduan Kreatif Membuat Bahan Ajar Inovatif. Jogjakarta: DivaPress.

Rusman. 2013. Belajar dan Pembelajaran Berbasis Komputer Mengembangkan Profesionalisme Guru Abad 21. Bandung: Alfabeta.

Sudjana. 1995. Metoda Statistika. Bandung: Tarsito.

Sugiyono. 2011. Metode Penelitian Pendidikan (Pendekatan kuantitatif, Kualitatif, dan $R \& D)$. Bandung: Alfabeta

Trianto. 2011. Mendesain Model Pembelajaran Inovatif-Progresif.Jakarta: Prenada Media Group. 